\title{
DEVELOPING ENGLISH PRINTED MATERIAL ON THEME OF OCCUPATION FOR EARLY YOUNG LEARNERS AT PAUD TERPADU JOY KIDS MAKAssaR
}

\author{
EkaYusmiyati \\ Universitas Islam NegeriAlauddin Makassar \\ ekaaysmyt@gmail.com \\ Kamsinah, \\ Universitas Islam NegeriAlauddin Makassar \\ kamsinah@uin-aluddin.ac.id \\ Sitti Nurpahmi \\ Universitas Islam NegeriAlauddin Makassar \\ Sitti.nurpahmi@uin-alauddin.ac.id
}

DOI: https://doi.org/10.24252/elties.v3i1.16487

\begin{abstract}
The main objective of this research is to develop English language materials for early young learners. This research was conducted at PAUD Terpadu Joy Kids Makassar. This research developed "Occupation" material with the sub-theme of "firefighter." The Research and Development model implemented in this study was ADDIE model in developing the material. The preliminary study results in this study show that English is not a compulsory subject but only an interlude. Therefore, researchers developed English language material following the applicable curriculum. The development of material in this study emphasized vocabulary recognition. Teachers and students can use the products that researchers would produce to carry out English learning activities. Keywords: English Printed Material, Early Young learners, Occupation.
\end{abstract}

\section{INTRODUCTION}

English learning material becomes a source of knowledge used by teachers in delivering material to students. As Ilmiah \& Nur (2018: 68) stated, there is an essential component in learning and teaching English material. Besides, English material can be adequate preparation for teaching and learning because it will guide both teachers and students over the whole course. English material has a crucial component in learning and teaching English. Therefore all schools provide various types of English materials. Textbooks, handouts, and modules are kinds of teaching material that Tomlinson usually uses (2011). The United States Environmental Protection Agency also stated that printed material is still the easiest and the most effective media to serve information 
on a project or issue or publicize a participation process. Although English material is the crucial component in the English and teaching process, it does not make English a compulsory subject but only as an interlude subject. As stated by the Ministry of Education and Culture, for the 2013 education curriculum that English in kindergartens and elementary schools is not a compulsory subject for students (Tomlinson, 2011).

In this research, the researchers conducted a preliminary study on Tuesday, June 25th, 2019, and found that kindergarten's English material was still insufficient as teaching material. The researcher's observation by asking one of the teachers of PAUD Terpadu Joy Kids shows that they use the magazine "Citra TK" as a source to learn English. However, English material and other worksheets were contained in the magazine only one page and served in Bahasa. Therefore, to achieve progress in learning English, the development of English learning materials is vital.

Learning English in this era is very important. There are several theories that researchers are not relevant to learning the process of young learners, especially for learning a language. OlpińskaSzkielko (2015: 63) points out that 3 to 5 years old students are called sensitive periods or golden moments for children to study a language. They still depend on language acquisition so that the process of acquiring a new language will be more successful than at a later age. Reilly and Ward (1997) also stated that children between 3 and 5 years old have not read and entered the schooling system. It is similar to the belief that "younger is better" (Pransiska, 2016: 251). In this case, teaching English to young learners is the right thing because the children's language acquisition ability becomes a fast learner. It is proved by the moment when children are easy to absorb and imitate everything around them as Pransiska (2016: 250) states that young learners are like a sponge. They soak up everything said around them and how it is said.

Therefore, the researcher will design and develop English material related to English material development based on student needs, focusing on occupation themes. Through this research, the researchers develop a new English material to make children interested in learning English. Some literature such as vocabulary, pictures, and tasks compiled in this theme (Suyanto, 2014: 101) can help the teacher explain the material for the children or student easily and be clear to understand. According to Olpińska(2015: 64), using pictures to describe an item for early young learners is essential. Using pictures will provide a flexible opportunity to gain an understanding of a thing easily. The researcher decided to develop English material. The researchers then decided to develop English printed material for early young learners based on the "Occupation" theme. 


\section{RESEARCH METHOD}

\section{Respondents}

The subject of this research was kindergarten students who were at the level of early young learners. Additionally, there were also other additional research participants taking part in order to conduct need analysis. Therefore, this research employed multiple data sources by inviting 20 learners, one teacher of PAUD Terpadu Joy Kids, and two English Education Department experts.

\section{Instruments}

The researcher used four instruments: interview guideline, observation checklist, documents (syllabus and the existing material), and validation checklist.

\section{Procedures}

The research design used here is developmental research. Latif (2012) stated that developmental research involves classroom problems, studying recent educational product development theories, developing the educational products, validating the product to experts, and field testing the product. The researcher applies ADDIE model. However, the researcher used the ADDIE model as a research model in developing material. ADDIE is an acronym that stands for Analysis, Design, Development, Implementation, and Evaluation. One of the most commonly used models in producing a practical design in a learning guide design is the ADDIE model (Aldoobie: 2015).

\section{Data analysis}

The data received from the interview would be analyzed in two ways those are qualitatively and quantitatively. The result of the questionnaire is analyzed quantitatively, and the data from the interview is analyzed qualitatively.

\section{Quantitative analysis}

In gathering judgment of the experts' research product to validate the material, the researcher used a validation checklist or review checklist. Each response of the statement consists of a "yes or no" answer. The resulting total of response presented the evaluation result of the product, which is accounted by using manual formula as follows:

$$
\mathrm{P}=\frac{f}{n} \times 100 \%
$$

$n$ 
Symbols:

$\mathrm{P}=$ Presentation

$\mathrm{F}=$ the Frequency of the Responses

$\mathrm{N}=$ the Ideal Score Total

$100 \%=$ Percentage

After obtaining the response's total, the data would be converted to the rating scale, which shows the product's final grade.

Table 2.Rating Scale

\begin{tabular}{|c|c|}
\hline Grade Scale & Verbal Scale \\
\hline $81-100$ & Very Good \\
\hline $61-80$ & Good \\
\hline $41-60$ & Sufficient \\
\hline $21-40$ & Bad \\
\hline $0-20$ & Very Bad \\
\hline
\end{tabular}

Source: Sugiono, 2012, p.95

\section{Qualitative analysis}

a. Reading/memoing

At this step, the researcher began to read and memoing some essential things to get the data that is important for the research.

b. Describing

Conveying research's complexity, the researchers describe the development and comprehensive descriptions of the participants and the phenomenon that have been studied.

c. Classifying

In this phase, the researcher distinguished the data by classifying them into more general categories. This phase intends to build connections among the data in order that the data would be perceptible.

\section{FINDINGS AND DISCUSSION}

The findings of the research were the result of the data analysis. The data were analyzed quantitatively and qualitatively. For the qualitative data, the researcher interviewed the teacher and document analysis. The result was elaborated as follows; 
The Needs of the Early Young Learners at PAUD Terpadu Joy Kids Makassar for English Printed Material on Theme of Occupation

\section{a. Reviewing Need Inventory for The Linguistic Need}

1) Learning Ability

Based on an analysis of interviews with teachers about students 'English learning abilities, it could be seen that students' English skills in the vocabulary field are still at a basic level. They still need more opportunities to improve and expand their vocabulary.

2) Learning Priority

In this section, the researchers prioritize what material is appropriate for students in the level of kindergarten. The interviews with the teacher showed that the material introduced for children in the form of basic materials such as vocabulary, numbers, simple sentences, and art activities

\section{b. Reviewing Needs Inventory for Learning Need}

1) Students Learning Problems

Based on the interview result point 4 and the observation of the existing material, the students in PAUD Terpadu Joy Kids Makassar had difficulty in learning English for the causes; The students had less reference for English activity, The students had less reference for thematic vocabulary; The students were easy to get bored in uninteresting material.

2) Students Learning Preferences

Student learning preference, in this case, aims to determine whether students feel comfortable and achieve their goals in receiving material interspersed with play.

Based on the results of interviews with teachers, students prefer learning while playing. Besides, they are also more interested in learning to use tangible things because it makes it easier for them to understand the teacher's material. Besides, students are also more interested in receiving material that has teaching materials designed in full colour.

3) Students Learning Style

Following the interview results from students' learning preferences, the learning styles are suitable for kindergarten students. Learning through playing; Learning by a picture; Learning by video; Learning by audio; Learning through exciting material.

The Design of the English Printed Material for Early Young Learners at PAUD Terpadu Joy Kids Makassar

In this research, the researchers designed a prototype and syllabus. This syllabus design is a guideline for researchers in making learning material. 
The prototype syllabus designed by the researcher can be seen as follows:

Tabel 3: Prototype Syllabus

\begin{tabular}{|c|c|c|c|c|c|c|}
\hline $\begin{array}{c}\text { Theme } \\
\text { / Sub } \\
\text { Theme }\end{array}$ & Basic Competence & Indicator & Learning Activity & $\begin{array}{c}\text { Media/ } \\
\text { Learning } \\
\text { Source }\end{array}$ & $\begin{array}{l}\text { Evaluati } \\
\text { on }\end{array}$ & $\begin{array}{c}\text { Durati } \\
\text { on }\end{array}$ \\
\hline $\begin{array}{c}\text { Occup } \\
\text { ation } \\
\text { "Fire } \\
\text { Fighte } \\
\text { r" }\end{array}$ & $\begin{array}{l}\begin{array}{l}3.12 \text { Recognizing early } \\
\text { literacy through } \\
\text { playing }\end{array} \\
4.12 \text { Showing the skill } \\
\text { of early literacy } \\
\text { through playing }\end{array}$ & $\begin{array}{l}3.12 .1 \text { Imitating the } \\
\text { pronunciation of the } \\
\text { alphabet in English } \\
3.12 .2 \text { Imitating the } \\
\text { spelling of word } \\
\text { about firefighter } \\
4.12 .1 \text { Showing the } \\
\text { ability to understand } \\
\text { the alphabet in } \\
\text { English. } \\
\text { 4.12.1 Showing the } \\
\text { skill of recognizing } \\
\text { the alphabet. }\end{array}$ & $\begin{array}{l}\text { "Repeat After Me" } \\
\text { (Teacher leads the } \\
\text { students to pronounce } \\
\text { alphabet) } \\
\text { "Spelling Words" } \\
\text { the students are asked to } \\
\text { follow the teacher after } \\
\text { the teacher spelling the } \\
\text { words about a } \\
\text { firefighter. } \\
\text { "Arrange the letter." } \\
\text { The student arranges the } \\
\text { letter into a word after } \\
\text { the teacher says the } \\
\text { letter. } \\
\text { "Tracing The words." } \\
\text { The student is tracing } \\
\text { the word. }\end{array}$ & $\begin{array}{ll}\text { - } & \text { Learning } \\
& \text { material } \\
\text { - } & \text { Pictures } \\
\text { - } & \text { Realia } \\
\text { - } & \text { Teachers } \\
& \text { voice }\end{array}$ & $\begin{array}{l}\text { Observati } \\
\text { on }\end{array}$ & $15 \mathrm{~m}$ \\
\hline
\end{tabular}

\section{The English Printed Material on Theme of Occupation Developed for Early Young Learners}

Designing the syllabus, researchers began to develop the material. In this section, the researchers make lesson plans and learning activities following the syllabus. According to Jolly and Bolitho (2011: 113), several procedures need to be done in developing material as follows:

\section{a. Identifying Students' Need over The Material}

The researcher has conducted interviews with PAUD Terpadu Joy Kids teachers before developing the material. It aimed to find out what students need from the material. The PAUD Terpadu Joy Kids teacher provided the researcher with supporting data obtained from weekly lesson plans and daily lesson plans. 


\section{Volume 3 Number 01, March 2021}

\section{b. Exploring student's Needs}

After gathering information about what is needed by students, the researchers begin to describe the interviews' results and then begin to classify them. It helped researchers in determining the priorities of learning that will focus on the material developed.

\section{c. Contextual Realization of Material}

After the researcher determined the subject matter of the developed learning material, the next step that must be taken was to consider the compatibility between the materials developed with students to more effectively use the researcher's material.

\section{d. Pedagogical Realization of Material}

There are several things that researchers need to consider before making material, for example, considering the material facilities that would be developed. The researchers must provide teaching materials that are more easily understood and applied by teachers to facilitate teachers in delivering student material.

\section{e. Production of Material}

The final result of the development of material taken by the researchers was to produce the material. In this phase, the researcher created material based on the needs of students. Based on student needs analysis, the researcher developed "occupation" material, particularly on "firefighter." The material contained various activities that are more directed towards vocabulary based on the theme to the students.

All the activities included were organized based on several aspects of learning material such as:

a. Language

The language aspect refers to the ability of students to use language skills. In this process, the researchers prepare several activities to help students. There were eight activities which the researchers develop for this aspect. It can be seen as follows:

1) Repeat after me!

2) Spelling the words

3) Arranging letters

4) Tracing the words

5) Listen and Say

6) Connecting Line 
7) Repeat After Me

8) Water and Fire

b. Morality and Region

During the interview, the teacher explained how they delivered material on moral and religious aspects. During class learning, sometimes the teacher observes the behavior of students in the classroom. There were two activities that the researcher develops for this aspect. It can be seen as follows:

1) Good or Bad?

2) AsmaulHusna

c. Social-Emotional

In this activity, students are stimulated to build their character. The researchers prepare worksheets where students can decide what they should do when they face a particular situation. There were two activities that the researchers developed for this aspect. It can be seen as follows:

1) Save the people

2) Arranging the pictures

d. Cognitive

The cognitive aspect stimulates students to improve their thinking skills during the learning process. Therefore, the researchers give them activities related to students' thinking processes in solving a problem. There were three activities which the researcher develops for this aspect. It can be seen as follows:

1) Label the fire Truck

2) How Many?

3) Show Me

e. Physics - Motoric

In developing material, the researchers considered student growth. Therefore, the researchers provided learning activities that support student kinesthetic improvement. These involved students were moving more actively during the learning process. There was one activity that the researcher develops for this aspect. It can be seen as follows:

1) Step to use an extinguisher

f. Art 
This section provides student activities that enable students to express their creativity and build their confidence. There were two activities that the researcher develops for this aspect. It can be seen as follows:

1) Sing a song

2) Colouring Things

\section{The Evaluation Result of English Printed Material on the theme of Occupation for Early Young Learners at PAUD Terpadu Joy Kids Makassar}

This phase is the last phase conducted by the researchers based on the ADDIE model used. In this section, the researcher considered whether the material is appropriate or not applied by the teacher. At this stage, evaluation is needed. Therefore, three types of evaluations would be conducted to determine the appropriateness of the material made by the researcher. That is a selfevaluation that the researcher will carry out, peer evaluation that another researcher will carry out, and finally, the expert evaluations that experts certainly handle are Joykids Integrated PAUD teachers. In evaluating what is being developed, experts used the Evaluation checklist.

\section{Self-Evaluation}

In this study, the researchers developed English-language teaching materials for PAUD TerpaduJoykids students. Before conducting this research, the researchers began to need analysis to determine student needs. Material related to the theme of "Occupation" according to the need

for the researchers' analysis. Within the theme, there is a sub-theme, "firefighter." This theme is related to the theme used at school.

\section{Peer Evaluation}

In this section, the researcher conducted a peer evaluation to assess the material that had been developed. As Hutchinson and Water (1998) state, one evaluation in reviewing the product is peer evaluation, which can help the researcher assess the material developed.

The first evaluator stated that there is an activity in which the title is entirely inappropriate. The second evaluator suggested adding a barcode. The third evaluator stated that the sequence of learning activities was still lacking. The fourth evaluator stated that there were activities that did not include aspects and core and basic competencies.

Based on the results of the peer evaluation, it can be concluded that the whole material showed that the material which the researcher has created has been good by covering the need of students, 
and it has been adjusted to the basic competence, the indicator, and the curriculum content for kindergarten. Moreover, it also contained pictures and barcodes in every activity.

Table 4. Peer Evaluation Result

\begin{tabular}{|c|c|c|}
\hline Aspect & Indicator & Items \\
\hline $\begin{array}{l}\text { The relevance of the } \\
\text { material (Tomlinson, 2013) }\end{array}$ & $\begin{array}{l}\text { 1. The appropriateness of the } \\
\text { material for childhood education } \\
\text { in introducing English } \\
\text { 2. The appropriateness of the } \\
\text { material toward the students' need } \\
\text { 3. The appropriateness of English } \\
\text { material toward the age of students }\end{array}$ & 30 \\
\hline $\begin{array}{l}\text { The thematic material to } \\
\text { introduce "Environment" in } \\
\text { English (Soni, 2015) }\end{array}$ & $\begin{array}{l}\text { 1. The appropriateness of } \\
\text { Environment theme for childhood } \\
\text { education } \\
\text { 2. The Environment theme as a part } \\
\text { of students' interest } \\
\text { 3. The influence of Environment } \\
\text { theme for students' English } \\
\text { learning }\end{array}$ & 30 \\
\hline $\begin{array}{l}\text { The learning activities in the } \\
\text { developed material (Soni, } \\
\text { 2015) }\end{array}$ & $\begin{array}{l}\text { 1. The variety of activity in the } \\
\text { developed English material } \\
\text { 2. The influence of English material } \\
\text { toward students' active } \\
\text { participation } \\
\text { 3. The influence of English material } \\
\text { for students to practice English }\end{array}$ & $\begin{array}{l}0 \\
30\end{array}$ \\
\hline $\begin{array}{l}\text { The skill and the } \\
\text { competence in the } \\
\text { developed material } \\
\text { (Suyanto,2007) }\end{array}$ & $\begin{array}{l}\text { 1. The influence of English material } \\
\text { on students English skill } \\
\text { development }\end{array}$ & 50 \\
\hline
\end{tabular}




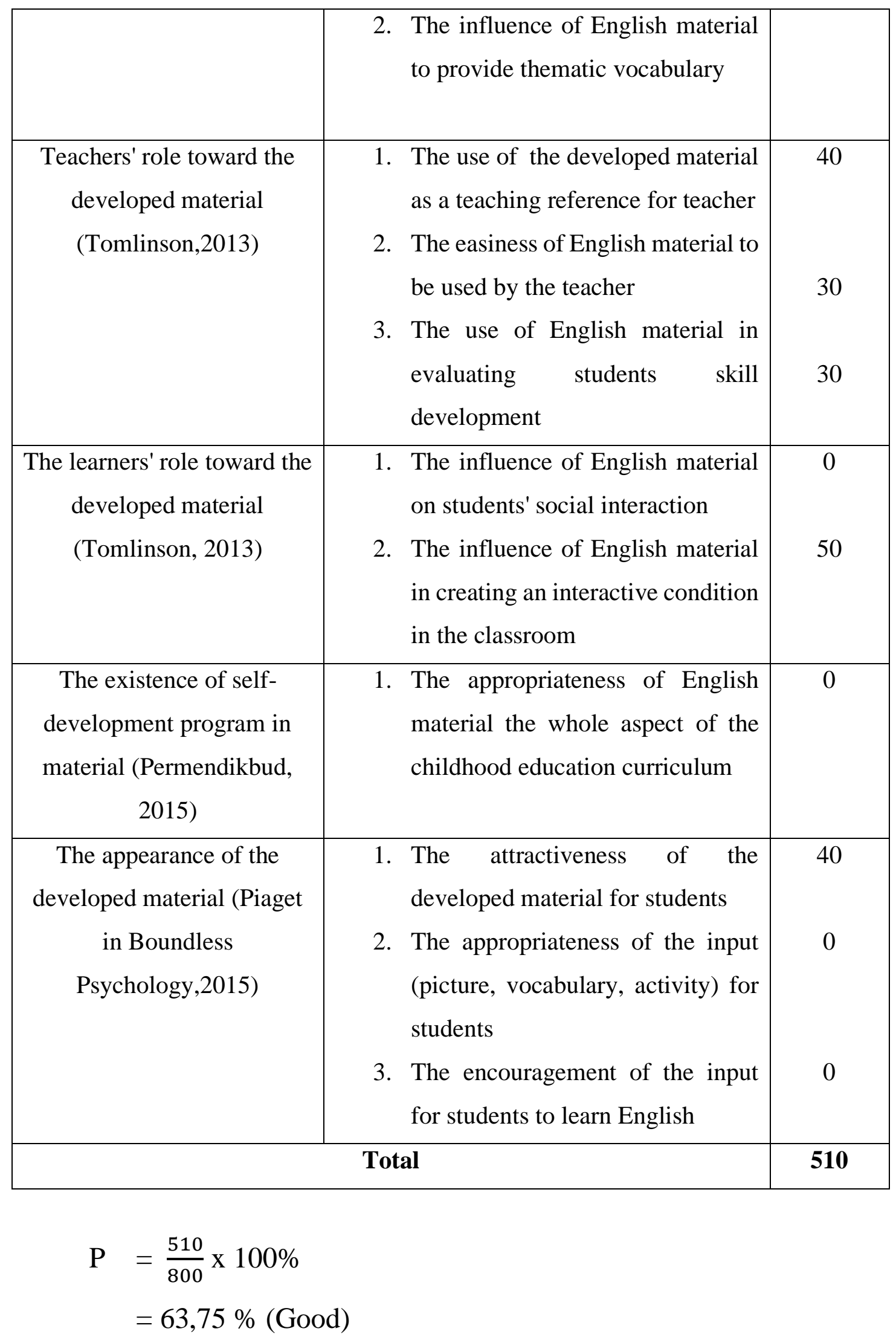




\section{Expert validation result}

Expert validation is the final evaluation stage that the researchers used to determine and ascertain whether the material that has been developed is suitable for use. In this section, the researcher invited two experts who are experts in their fields. The two experts were from Alauddin State Islamic University of Makassar, the Islamic Childhood Education Department lecturer, and another is from English Education Department.

The validation process was carried out twice. The first, the expert suggested making steps for learning activities, and the second, the expert evaluated the material as a whole, and the material has been good and has been appropriate to the theme.

Table. 5 Expert Validation Result

\begin{tabular}{|c|c|c|}
\hline Aspect & Indicator & Items \\
\hline $\begin{array}{l}\text { The relevance of the } \\
\text { material (Tomlinson, 2013) }\end{array}$ & $\begin{array}{l}\text { 1. The appropriateness of the } \\
\text { material for childhood education } \\
\text { in introducing English } \\
\text { 2. The appropriateness of the } \\
\text { material toward the students' need } \\
\text { 3. The appropriateness of English } \\
\text { material toward the age of students }\end{array}$ & 30 \\
\hline $\begin{array}{c}\text { The thematic material to } \\
\text { introduce "Environment" in } \\
\text { English (Soni, 2015) }\end{array}$ & $\begin{array}{l}\text { 1. The appropriateness of } \\
\text { Environment theme for childhood } \\
\text { education } \\
\text { 2. The Environment theme as a part } \\
\text { of students' interest } \\
\text { 3. The influence of Environment } \\
\text { theme for students' English } \\
\text { learning }\end{array}$ & 40 \\
\hline $\begin{array}{l}\text { The learning activities in the } \\
\text { developed material (Soni, } \\
\text { 2015) }\end{array}$ & $\begin{array}{l}\text { 1. The variety of activity in the } \\
\text { developed English material } \\
\text { 2. The influence of English material } \\
\text { toward students' active } \\
\text { participation }\end{array}$ & 40 \\
\hline
\end{tabular}




\begin{tabular}{|c|c|c|}
\hline & $\begin{array}{l}\text { 3. The influence of English material } \\
\text { for students to practice English }\end{array}$ & 30 \\
\hline $\begin{array}{l}\text { The skill and the } \\
\text { competence in the } \\
\text { developed material } \\
\text { (Suyanto,2007) }\end{array}$ & $\begin{array}{l}\text { 1. The influence of English material } \\
\text { on students English skill } \\
\text { development } \\
\text { 2. The influence of English material } \\
\text { to provide thematic vocabulary }\end{array}$ & 50 \\
\hline $\begin{array}{l}\text { Teachers' role toward the } \\
\text { developed material } \\
\text { (Tomlinson,2013) }\end{array}$ & $\begin{array}{l}\text { 1. The use of the developed material } \\
\text { as a teaching reference for teacher } \\
\text { 2. The easiness of English material to } \\
\text { be used by the teacher } \\
\text { 3. The use of English material in } \\
\text { evaluating students } \\
\text { development }\end{array}$ & 30 \\
\hline $\begin{array}{l}\text { The learners' role toward the } \\
\text { developed material } \\
\text { (Tomlinson, 2013) }\end{array}$ & $\begin{array}{l}\text { 1. The influence of English material } \\
\text { on students' social interaction } \\
\text { 2. The influence of English material } \\
\text { in creating an interactive condition } \\
\text { in the classroom }\end{array}$ & 0 \\
\hline $\begin{array}{l}\text { The existence of self- } \\
\text { development program in } \\
\text { material (Permendikbud, } \\
\text { 2015) }\end{array}$ & $\begin{array}{l}\text { 1. The appropriateness of English } \\
\text { material the whole aspect of the } \\
\text { childhood education curriculum }\end{array}$ & 0 \\
\hline $\begin{array}{c}\text { The appearance of the } \\
\text { developed material (Piaget } \\
\text { in Boundless } \\
\text { Psychology,2015) }\end{array}$ & $\begin{array}{l}\text { 1. The attractiveness of the } \\
\text { developed material for students } \\
\text { 2. The appropriateness of the input } \\
\text { (picture, vocabulary, activity) for } \\
\text { students } \\
\text { 3. The encouragement of the input } \\
\text { for students to learn English }\end{array}$ & 40 \\
\hline
\end{tabular}




$$
\begin{aligned}
P & =\frac{550}{800} \times 100 \% \\
& =68,75 \%(\text { Good })
\end{aligned}
$$

\section{CONCLUSION}

1. The researcher conducted a need analysis by conducting an interview with the teacher at PAUD Terpadu Joy Kids Makassar and observing some kindergarten documents, including the syllabus, the lesson plan, and the existing material (Citra TK) develop English material based on the theme of Occupation. The researchers also made observations and analyzed the results of interviews to make English material according to student needs.

2. The focus of the researcher's material is vocabulary, numbers, phrases, simple sentences, and the art of integrating activities into six self-development programs (Morality and Religion, Social-Emotional, Cognitive, Physical-Motoric, Language, and Art). In addition to the material being developed, the researchers also attached barcodes to several worksheets.

3. The English materials made by the researchers have been well designed for early childhood according to their needs. This is based on the results of expert validation.

\section{REFERENCES}

Aldoobie, Nada. (2015) .ADDIE Model. American International Journal of Contemporary Research, 5, 68

Education and Culture Ministry of Indonesia. (2015). The Regularity of Education and Culture Ministry of Indonesia Number 145 the Year 2014 for Childhood Education Curriculum 2013

Ilmiah, Nur, Nur Aliyah Nur. (2018). Developing Asking and Giving Information Materials Dealing with 2013 Curriculum of SMP Eight Grade. Alauddin State Islamic University of Makassar

Jolly, D., R, Bolitho. (2011). A framework for materials writing. In: Tomlinson, B. (ed) Materials Development in Language Teaching. (2nded) Cambridge: Cambridge University Press 


\section{Volume 3 Number 01, March 2021}

Latif, M. A. (2012). Research Methods on Language Learning (An Introduction).Malang: UM Press

Nurpahmi, S. (2014). English for Specific Purposes: Integrated Approach (A. Sardian Maharani Asnur, Ed.). Makassar: Alauddin Universisity Press.

Nurpahmi, S. (2017). Esp Course Design: An Integrated Approach. Lentera Pendidikan, 19(2), $172-181$.

Nurpahmi, S. (2013). An Introduction to English for Specific Purposes. Makassar: Alauddin University Press.

Olpińska, M. (2015). Teaching Materials for English in The Primary Education -also for the preschool education?. Uniwersytet Warszawski

Pransiska, R.(2016). Requirements of Teaching English for Young Learners: an Overview in Padang, West Sumatera

Tomlinson Brian (2013). Developing Materials for Language Teaching ( $2^{\text {nd }}$ Ed). United Kingdom: Bloomsbury

Tomlinson, Brian. (2011). Material development in Language Teaching ( $2^{\text {nd }}$ Ed.). Cambridge: Cambridge University Press. 